\title{
Telescoping of isotherms beneath the South Tibetan Detachment, Mount Everest Massif: implications for magnitude of internal flow during extrusi on of the Greater Himalayan Slab
}

\author{
Richard D Law ${ }^{1 *}$, Micah J Jessup ${ }^{2}$, Michael P Searle ${ }^{3}$, John M Cottle ${ }^{3}$ and David Waters ${ }^{2}$ \\ 1 Department of Geosciences, Virginia Tech, Blacksburg, VA24061, USA \\ 2 Department of Earth \& Planetary Sciences, University of Tennessee, Knoxville, TN 37969, USA \\ 3 Department of Earth Sciences, University of Oxford, Oxford OX1 3PR, UK \\ * For correspondence, email: rdlaw@vt.edu
}

Both petrologic and microstructural/crystal fabric data indicate that isotherms recorded in the schists and gneisses of the Greater Himalayan Slab (GHS) and located in the footwall to the South Tibetan Detachment System (STDS) have undergone extreme telescoping during penetrative flow associated with southward extrusion of the GHS from beneath the Tibetan Plateau. Within the Rongbuk Valley located to the north of Mount Everest we have made vertical sampling traverses working downward from the STDS into the GHS at Hermit's Gorge, Rongbuk Monastery and the northern entrance to Rongbuk Valley. Adopting the calibration of Kruhl (1998) and Law et al. (2004), deformation temperatures were estimated using the opening angle of cross girdle c-axis fabrics measured by optical microscopy in plastically deformed and dynamically recrystallized quartz grains in each sample. Traced from south to north, linear regression of the deformation temperature data indicates apparent thermal gradients of 420,385 and $369^{\circ} \mathrm{C}$ per km for the Hermit's Gorge, Rongbuk Monastery and northern sampling transects respectively (Figure
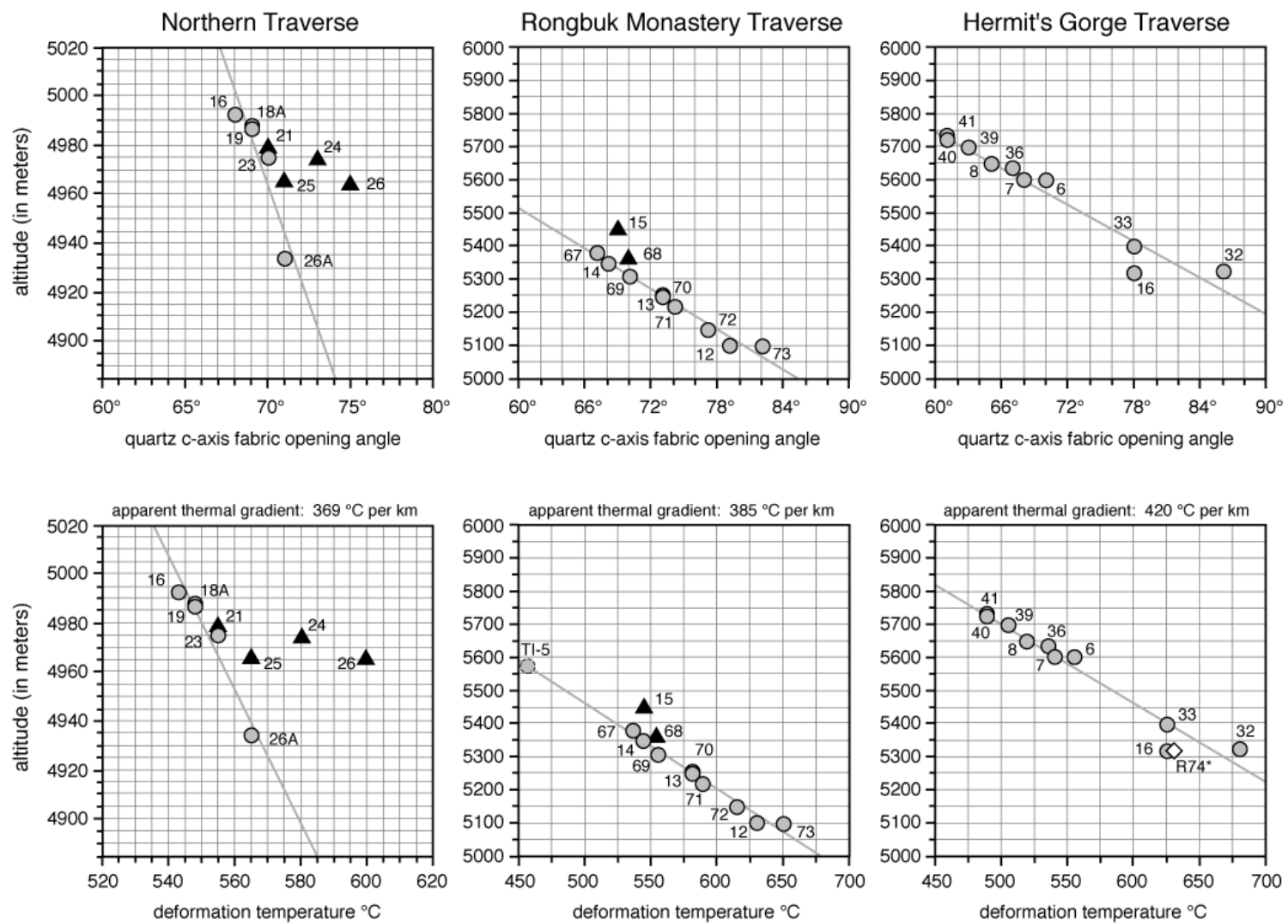

FIGURE 1. Upper row: opening angle of cross-girdle c-axis fabrics versus sampling altitude in (from north to south) the Northern, Rongbuk Monastery and Hermit's Gorge traverses. Gray circles and black triangles indicate data from metasedimentary rocks and leucogranite sills respectively. Linear regression lines for opening angle versus altitude (metasedimentary rocks only) are shown. Lower row: deformation temperatures (using the calibration of Kruhl 1998 and Law et al. 2004) versus sampling altitude. Linear regression lines (metasedimentary rocks only) used to estimate apparent thermal gradients are show. Note deformation temperatures estimated for leucogranites at a given altitude are always greater than those for metasedimentary rocks suggesting that leucogranites cooled during deformation. Open diamond symbol (sample R74) in Hermit's Gorge traverse indicates phase-equilibria based temperature data of Hodges et al. (1992) from same outcrop as our sample 16. 
1). Isothermal surfaces projected between these three traverses have an apparent dip of c. $2^{\circ}$ towards the NNE, parallel to the apparent sheet dip of foliation.

The observed telescoping of isotherms could be due to: a) penetrative strain associated with extreme vertical thinning, b) chilling from juxtaposition against cooler hanging wall rocks, or c) downward increasing transport of material during penetrative flow associated with southward extrusion of the GHS as assumed, for example, in channel flow models. Vertical penetrative thinning requires strain ratios of between 100:1 and 250:1 measured in XZ sections for which there is no supporting field or microstructural evidence - assuming geothermal gradients of $40-25{ }^{\circ} \mathrm{C}$ per $\mathrm{km}$ during plane strain deformation (as indicated by the cross girdle fabrics) at constant volume. Chilling against cold hanging wall rocks is a possibility requiring further analysis, but in itself implies significant (at least tens of kilometers) transport in order to place hot GHS footwall rocks against cooler Tethyan hanging wall rocks.

Adopting the differential transport model, simple geometric analysis using cross sections drawn parallel to the local $030^{\circ}$ transport direction indicated by stretching lineations in the GHS suggests that detachment-parallel transport magnitudes of 25-85 $\mathrm{km}$ are needed to place rocks originally deforming at $675^{\circ} \mathrm{C}$ at no more than $0.5 \mathrm{~km}$ beneath stationary rocks at $475^{\circ} \mathrm{C}$, assuming geothermal gradients of 40 to $25^{\circ} \mathrm{C}$ and particle paths parallel to an overlying planar STDS dipping at between 10 and $5^{\circ}$ to the north. Perhaps more realistically, if both the reference rock particles at
475 and $675^{\circ} \mathrm{C}$ are moving during extrusion, and do not become coupled at a vertical spacing of $0.5 \mathrm{~km}$ until they pass through the brittle-ductile transition zone $\left(\right.$ c. $\left.300^{\circ} \mathrm{C}\right)$, then detachment parallel transport magnitudes of 85-170 and $45-85 \mathrm{~km}$ are indicated for the 675 and $475^{\circ} \mathrm{C}$ reference particles respectively, with differential transport on the order of $45-85 \mathrm{~km}$ between these reference particles. These particle transport estimates are similar to those previously calculated from petrologically determined barometry data of GHS rocks in the Everest region (Searle et al. 2003) and are at least compatible with recently published channel flow models for extrusion and exhumation of the GHS.

\section{References}

Hodges KV, RR Parrish, TB Housch, DR Lux, BC Burchfiel, LH Royden and Z Chen. 1992. Simultaneous Miocene extension and shortening in the Himalayan orogen. Science 258: 1466-1470

Kruhl JH. 1998. Reply: Prism- and basal-plane parallel subgrain boundaries in quartz: a microstructural geothermobarometer. Journal Metamorphic Petrology 16: 142-146

Law RD, MP Searle and RL Simpson. 2004. Strain, deformation temperatures and vorticity of flow at the top of the Greater Himalayan Slab, Everest Massif, Tibet. Journal of Geological Society of London 161: 305-320

Searle MP, RL Simpson, RD Law, RR Parrish and DJ Waters. 2003. The structural geometry, metamorphic and magmatic evolution of the Everest massif, High Himalaya of Nepal - South Tibet. Journal of Geological Society of London 160: 345-366 